\title{
Effect of Smoking on the Lipid Profile of Inhabitant Smokers of Hasilpur, District Bahawalpur, Pakistan
}

\author{
Mushtaq Hussain Lashari1,*, Sumbel Sumera ${ }^{1}$, Umer Farooq², Zia Ur Rehman², Nuzhat Sial ${ }^{1}$, Farooq Ahmad", \\ Fozia Afzal', Muhammad Saleem Aktar ${ }^{3}$, Muhammad Nawaz ${ }^{4}$, A. B. Gulshan ${ }^{5}$ \\ 1Department of Zoology, The Islamia University of Bahawalpur, Punjab, Pakistan \\ 2University College of Veterinary and Animal Sciences, The Islamia University of Bahawalpur, Punjab, Pakistan \\ ${ }^{3}$ Faculty, of Veterinary Sciences, Bahauddin Zakariya University, Multan, Punjab, Pakistan \\ ${ }^{4}$ Department of Environmental Science, Bahauddin Zakariya University, Multan, Punjab, Pakistan \\ ${ }^{5}$ Department of Botany, Ghazi University D.G. Khan, Punjab, Pakistan
}

\section{ABSTRACT}

Background: Health problem are culturally associated with smoking in developing countries. Many hazardous chemicals are taken up by direct or passive smoking causing lipid peroxidation resulting in oxidative stress.

Objectives: To estimate the occurrence of smoking and its effects on the lipid profile in populations of Hasilpur, Pakistan.

Methodology: The current study was conducted from April - August 2014. Out of 247 apparently healthy subjects of both genders (male=220; female=27), 134 were smokers and 113 were non-smokers. In order to analyze lipid profile, blood samples were collected in early morning hours from the selected members who were asked to fast all night. By using Chem-100 chemistry analyzer, cholesterol, triglyceride, HDL, LDL and VLDL were analyzed.

Results: The overall prevalence of smokers was $54.25 \%$. The results showed $60.9 \%$ prevalence in males and $0 \%$ in females. The mean value of serum triglyceride in control, light smokers and heavy smokers was $147.4 \pm 11.7 \mathrm{mg} / \mathrm{dl}, 190.8 \pm 41.4$ and $205.3 \pm 29.7 \mathrm{mg} / \mathrm{dl}$, respectively. The results of cholesterol in control, light smokers and heavy smokers were $147.38 \pm 7.99 \mathrm{mg} / \mathrm{dl}, 136.8$ $\pm 12.8 \mathrm{mg} / \mathrm{dl}$ and $173.44 \pm 8.63 \mathrm{mg} / \mathrm{dl}$, respectively. There was a considerable distinction in the mean level of serum triglyceride and cholesterol between the control group, light smokers and heavy smoker groups $(P<00.5)$. The mean value of $\mathrm{HDL}$ of control, light smokers and heavy smokers was $30.93 \pm 1.30 \mathrm{mg} / \mathrm{dl}, 31.10 \pm 2.45$ and $34.58 \pm 1.55 \mathrm{mg} / \mathrm{dl}$, respectively. The mean values of $L D L$ and VLDL of control, light smokers and heavy smokers were $110.46 \pm 3.63 \mathrm{mg} / \mathrm{dl}, 106.00 \pm 4.52 \mathrm{mg} / \mathrm{dl}, 117.19 \pm 3.48 \mathrm{mg} / \mathrm{dl}$ and $33.54 \pm 3.11 \mathrm{mg} / \mathrm{dl}, 49 \pm 9.02 \mathrm{mg} / \mathrm{dl}, 41.06 \pm 5.34 \mathrm{mg} / \mathrm{dl}$, respectively. There was significant difference in the mean level of HDL, LDL and VLDL between the control group, light smokers and heavy smoker groups $(P<0.05)$.

Conclusion: This study concluded that smoking is the reasons of variation in the lipid profile. Elevated period of smoking and the number of smoked cigarettes/day reason the alteration in serum lipid levels and is probably related with increased danger for coronary artery disease.

\begin{tabular}{|c|c|c|}
\hline Keywords & *Address of Correspondence & Article info. \\
\hline $\begin{array}{l}\text { Lipid Profile, Smokers, Nonsmokers HDL, } \\
L D L, V L D L\end{array}$ & mushtaqlashary@gmail.com & $\begin{array}{l}\text { Received: March 11, } 2019 \\
\text { Accepted: December 31, } 2019\end{array}$ \\
\hline $\begin{array}{l}\text { Cite this article: Lashari } M H \text {, Sumera S, Far } \\
\text { Smoking on the Lipid Profile of Inhabitant S }\end{array}$ & kers of Hasilour District Bahav & $\begin{array}{l}\text { Funding Source: Nil } \\
\text { Conflict of Interest: Nil }\end{array}$ \\
\hline
\end{tabular}

This is an Open Access article distributed under the terms of the Creative Commons Attribution License (http://creativecommons.org/licenses/by/4.0), which permits unrestricted use, distribution, and reproduction in any medium, provided the original work is properly cited.

\section{INTRODUCTION}

Nowadays, smoking is the cause of rising health problems in developing countries ${ }^{1}$. Smoking is the essential reason of preventable death. Consistent with world health organization (WHO), fifty-four million tobacco-associated deaths were recorded globally in 2004 and use of tobacco is now conscientious for the demise of 1 in 10 adults 
around the world (as regards 5 million deaths/year) ${ }^{2,3}$. Many harmful chemicals and metabolites are taken up as a result of tobacco burning (cigarette smoking). These substances can be electrophilic which start the lipid peroxidation chain reactions in membranes and increase oxidative stress ${ }^{4}$. Cigarette smoking is commonly taken into consideration related to increased risk of clinical problems. Results of numerous studies showed that changing in the typical lipid profile is greatly associated with tobacco smoking 5,6. It also decreases immunity and for this reason, the potential to combat off illnesses, makes smokers more vulnerable to opportunistic infections. This reality has importance in smokers undergoing surgical procedures as they are afflicted by negative post-operative wound recuperation and an increased risk of superficial surgical site infections ${ }^{7}$. Abnormalities in plasma lipoprotein are the main dangerous aspect for common vascular atherosclerotic diseases ${ }^{8}$.

Tobacco utilization distort the lipid profile notably and this has been proved often and demonstrated in different studies which confirmed higher serum cholesterol, triglyceride, and LDL levels, in aggregate with the decrease HDL levels 9 . Lipids play a crucial function basically in all regards of biological life. Out of these, some act as hormones or hormones precursors, help in digestion, imparting power, and metabolic fuels. Lipids are also important structural components of bio-membranes and form an insulation which prevents the heat loss and assist in nerve impulses conduction ${ }^{10}$. There may be a dose-reactive association among the number of cigarettes smoked every day and cardiovascular morbidities and death ${ }^{11}$.

In Pakistan, smoking by way of males is generally up to code and considered to be habitual. However, smoking by means of females is taken into consideration unlawful. A large population of men might start smoking in teenage due to peer stress which is a main factor ${ }^{12}$. In Pakistan, it is predicted that the occurrence of tobacco smoking is higher in adult males in comparison to females. This study aims to discover the association of cigarette smoking, in consonance with the number of cigarettes smoked per day as well as the period of smoking and their impact on serum lipid profile.

\section{MATERIALS AND METHODS}

This study was conducted at the population of Hasilpur, district Bahawalpur, Pakistan throughout the duration from April to August 2014 comprising of 247 subjects which included males $(n=220)$ and females $(n=27)$ aged between 17-44 years and these have been classified into groups which include smokers and non-smokers. In group-I, 134 healthy males and females (non-smokers) were selected for the study, out of those 26 were subjected to a lipid profile test. In group-II, 134 males (smokers) were selected for study and 24 were subjected to lipid profile testing.

Group-II has been divided into subgroups relying upon period and intensity of smoking.

Group-II A $(n=8)$ smoke $1-5$ cigarettes per day, light smokers

Group-II B ( $n=16)$ smoke $>5$ cigarettes per day, heavy smokers

Every participant was interviewed at the time of sampling for numerous parameters like age, sex, caste, body weight and height. Then BMl (body mass index) was calculated by using height in inches and weight in ponds. In order to have significant results, overnight 12-14hours fasting blood samples were collected from subjects. The $5 \mathrm{ml}$ of venous blood was collected by means of venipuncture from all the volunteers. Blood samples collected have been sent to the physiology laboratory of the department of Zoology, The Islamia University of Bahawalpur for evaluation. The samples were centrifuged at 2000rpm for $10-15$ minutes. Lipid profile estimation which incorporates serum cholesterol, serum TG, HDL, LDL and VLDL was carried out using Chem-100 chemistry analyzer. The data were analyzed using Minitab software (version 13). The results were expressed as percentages and Mean \pm S.E.M (standard error mean). The distinction between mean values was evaluated through chi-square. The P-value of $<0.05$ was considered to be statistically significant.

\section{RESULTS}

The current study was carried out in and around Hasilpur district Bahawalpur. A total of 247 subjects were observed. The overall prevalence of smokers was $54.26 \%$ and non-smokers was $45.74 \%$ (Table 1). Gender wise 
prevalence was visible only in males and was completely absent in females (Table 2). The outcomes of the present study revealed non-significant increase in terms of mean serum triglyceride, HDL, LDL and VLDL level in smokers as compared to the non-smokers. However, mean of serum total cholesterol and triglycerides level of smokers was significantly higher than non-smokers (Table $\mathbf{3}$ ).

Table 1. The overall prevalence of smokers and nonsmokers inhabitants of Hasilpur district Bahawalpur,

Pakistan.

\begin{tabular}{ccc}
\hline $\begin{array}{c}\text { Total } \\
\text { observed }\end{array}$ & $\begin{array}{c}\text { Smokers } \\
\text { No. (Prevalence } \\
\%)\end{array}$ & $\begin{array}{c}\text { Non-Smokers } \\
\text { No. (Prevalence } \\
\%)\end{array}$ \\
\hline 247 & $134(54.26)$ & $113(45.74)$ \\
\hline
\end{tabular}

Table 2. Gender wise prevalence of smokers of inhabitants of Hasilpur district Bahawalpur, Pakistan.

\begin{tabular}{ccc}
\hline Gender & Male $(\mathrm{n}=220)$ & Female $(\mathrm{n}=27)$ \\
\hline Prevalence $(\%)$ & 60.9 & 0 \\
\hline
\end{tabular}

current study, overall prevalence of smokers in Pakistan is $54.25 \%$ (Table 1), and gender-wise higher prevalence rate i.e., $36 \%$ is recorded in males as indicated in (Table 2 ) with $9 \%$ prevalence, reported by other scientist ${ }^{16}$. The woman in developing nations tends to have decreased rate of smoking; begins smoking at a later age compared to males and consume much less cigarette every day. Smoking is not usual amongst muslim females due to the fact that Islamic teaching forbids smoking, considering it to be both distasteful and illegal ${ }^{17}$.

\section{Serum Triglycerides}

The present study revealed that the levels of mean serum triglyceride in smokers and non-smokers were $190.8 \pm 41.4 \mathrm{mg} / \mathrm{dl}$ and $200.4 \pm 23.7 \mathrm{mg} / \mathrm{dl}$, respectively (Table 2). The mean values of serum triglycerides $190.8 \pm 41.4 \mathrm{mg} / \mathrm{dl}$ were considerably decreased in light smokers as compared to heavy smokers with the mean of $205.3 \pm 29.7 \mathrm{mg} / \mathrm{dl}$. Current survey has recommended that levels of triglyceride are the crucial aspect leading to coronary heart disease. Cigarette smoking has been observed to raise the concentrations of triglycerides in

Table 3. (MEAN \pm S.E.M) Effect of cigarettes smoking on the lipid profile of inhabitants of Hasilpur district Bahawalpur, Pakistan.

\begin{tabular}{|c|c|c|c|c|}
\hline \multirow[t]{2}{*}{ S. No. } & \multirow[t]{2}{*}{ Parameters } & \multicolumn{2}{|c|}{ Smokers } & \multirow{2}{*}{$\begin{array}{c}\text { Non-Smokers } \\
(n=26)\end{array}$} \\
\hline & & $\begin{array}{l}\text { Smoke } 1-5 \text { cigarettes daily } \\
\qquad(n=8)\end{array}$ & $\begin{array}{l}\text { Smoke }>5 \text { cigarettes daily } \\
\qquad(n=16)\end{array}$ & \\
\hline 1 & Triglycerides (mg/dl) & $190.8 \pm 41.4$ & $205.3 \pm 29.7^{*}$ & $147.4 \pm 11.7$ \\
\hline 2 & Cholesterol (mg/dl) & $136.8 \pm 12.8$ & $173.44 \pm 8.63^{*}$ & $147.12 \pm 7.99$ \\
\hline 3 & LDL (mg/dl) & $106.00 \pm 4.52$ & $117.19 \pm 3.48$ & $110.46 \pm 3.63$ \\
\hline 4 & $\mathrm{HDL}(\mathrm{mg} / \mathrm{dl})$ & $31.10 \pm 2.45$ & $34.58 \pm 1.55$ & $30.93 \pm 1.30$ \\
\hline 5 & VLDL (mg/dl) & $49.00 \pm 9.02$ & $41.06 \pm 5.34$ & $33.54 \pm 3.11$ \\
\hline
\end{tabular}

Note: ${ }^{*}=$ statistically significant value $(P<0.05)$

\section{DISCUSSION}

In Pakistan, smoking itself is a primary cause of many health problems ${ }^{13}$. Smoking is one of the main gamble factors for a number of ailments along with different malignancies, particularly lungs. Previous studies showed that there are $87 \%$ chances of lung cancer in people who smoke. Smoking usually will increase the risk of developing lung cancer by way of 10 folds $^{14,15}$. In the comparison to non-smokers. Comparable outcomes were stated by Naisargi et al., (2013), Chauhan et al., (2012) and Elhashimi et al., (2013). The serum triglyceride levels in smokers became higher than non-smokers which were $173.44 \pm 46.87 \mathrm{mg} / \mathrm{dl}, \quad 173 \pm 56.65 \mathrm{mg} / \mathrm{dl}, \quad 147.8 \pm 62.4 \mathrm{mg} / \mathrm{dl}$ and $115.9 \pm 47.67 \mathrm{mg} / \mathrm{dl}, \quad 129.10 \pm 31.60 \mathrm{mg} / \mathrm{dl}, \quad 100.3 \pm$ $21.7 \mathrm{mg} / \mathrm{dl}$, respectively ${ }^{18-20}$. 


\section{Serum Cholesterol}

The present study also confirmed a significant increase in serum total cholesterol within the smokers as compare to non-smokers (Table 3). Higher level of cholesterol was related to coronary heart diseases and people who smoke generally have the higher quantity of LDL cholesterol in their blood circulation. Comparable results had been stated by Naisargi et al., (2013). In non-smokers, the total mean serum cholesterol was $166.08 \pm 28.71 \mathrm{mg} / \mathrm{dl}$ which was considerably greater in smokers, i.e., 194.06 \pm 37.6 $\mathrm{mg} / \mathrm{dl}^{18}$. Chauhan et al., (2012) and Elhashimi et al., (2013) documented the same result, i.e. in non-smokers cholesterol was $164.1 \pm 20.26 \mathrm{mg} / \mathrm{dl}, 191.29 \pm 46.3 \mathrm{mg} / \mathrm{dl}$, whilst it became considerably greater in smokers, i.e., $181 \pm 28.10 \mathrm{mg} / \mathrm{dl}, 133.3 \pm 24.5 \mathrm{mg} / \mathrm{dl}$, respectively ${ }^{19,20}$.

\section{High-Density Lipoprotein (HDL)}

In the present study, HDL -cholesterol level was not statistically different in smokers as compared with nonsmokers (Table 3). This finding is not consistent with the findings of Rosenson who stated that there may be a decrease in HDL-cholesterol degree in smokers ${ }^{21}$. According to Naisargi et al., 2013, HDL-cholesterol level become lowered in smokers in comparison with nonsmokers ${ }^{18}$. Especially HDL is known to be good cholesterol and is probably lower in smokers, however, the results of the current study show that smokers have a slightly increased value of HDL than non-smokers. This difference was not statistically different. Smoking has been documented to be related to low levels HDLcholesterol 5,6 .

\section{Low-Density Lipoprotein and Very Low-Density Lipoprotein (LDL and VLDL)}

In the current study, LDL and VLDL levels were also nonsignificantly higher in smokers than the non-smoker (Table 3). Results of Abdullah et al., 2009 are much like current research, such as having a mean of LDL-C and VLDL-C in smokers $(29 \pm 0.53 \mathrm{mmol} / \mathrm{l}$ and $0.37 \pm 0.05 \mathrm{mmol} / /$, respectively) have been significantly higher than in non-smokers $(2.74 \pm 0.48 \mathrm{mmol} / \mathrm{l}$ and $0.35 \pm 0.01 \mathrm{mmo} / /)$, respectively ${ }^{21}$. The similar result was also stated by Zamir et al., (2000) i.e., LDL \& VLDL levels had been significantly increased in smokers than non- smokers $206 \pm 4.38 \mathrm{mg} / \mathrm{dl}$ and $165 \pm 5.59 \mathrm{mg} / \mathrm{dl}$ and $113 \pm 4.10 \mathrm{mg} / \mathrm{dl}$ and $97 \pm 2.86 \mathrm{mg} / \mathrm{dl}^{22}$.

\section{CONCLUSION}

The findings of the current study recommended that smoking is likely associated to be the causal agent for variation in lipid profile. Inflicting abnormality in lipids values in people who smoked is noticeable. This could greatly increase if it is for longer period of time (years) as well as quantity of cigarettes per day. Further studies are required to link lipid profile with the duration of smoking as well as with gender and age at which smoking is started.

\section{LIST OF ABBREVIATIONS}

WHO

World Health Organization

LDL Low Density Lipoproteins

HDL High Density Lipoproteins

VLDL Very Low Density Lipoproteins

BMI Body Mass Index

SEM Standard Error Mean

LDL - C Low Density Lipoproteins - Cholesterol

VLDL $-\mathrm{C} \quad$ Very Low Density Lipoproteins Cholesterol

HDL - C High Density Lipoproteins - Cholesterol

\section{REFERENCES}

1. Adedeji $\mathrm{OA}$, Etukudo MH. Lipid profile of cigarette smokers in calabar municipality. Pakistan $\mathrm{J}$ Nut. 2006; 5(3):327-8.

2. Guindon G, Boisclair D. Past, current and future trends in tobacco use (english). Health, nutrition and population (hnp) discussion paper. Economics of tobacco control. Washington, DC: World Bank, 2003.

3. Alan D. Lopez SB, Ed Bos. Demographic and Epidemiological Characteristics of Major Regions, 1990-2001. In: Lopez AD, Mathers CD, Ezzati M, Jamison DT, Murray CJL, editors. Global Burden of Disease and Risk Factors. Disease Control Priorities Project Washington (DC) 2006.

4. Loeper J, Goy J, Rozensztajn L, Bedu O, Moisson P. Lipid peroxidation and protective enzymes during myocardial infarction. Clin Chim Acta. 1991;196 (2-3):119-25.

5. Guedes DP, Pinto Guedes JER, Barbosa DS, De Oliveira JA. Tobacco use and plasma lipid-lipoprotein profile in adolescents. Rev Assoc Med Bras. 2007;53(1):59-63. 
6. Arslan E, Yakar T, Yavaşoğlu İ. The effect of smoking on mean platelet volume and lipid profile in young male subjects. Anatolian J Card. 2008; 8(6):422-5.

7. Mehta H, Nazzal K, Sadikot RT. Cigarette smoking and innate immunity. Inflamm Res. 2008; 57(11):497503.

8. Shai I, Rimm EB, Hankinson SE, Curhan G, Manson $J A E$, Rifai $N$, et al. Multivariate assessment of lipid parameters as predictors of coronary heart disease among postmenopausal women: Potential implications for clinical guidelines. Circulation. 2004; 110(18):2824-30.

9. Wakabayashi I. A ssociations of alcohol drinking and cigarette smoking with serum lipid levels in healthy middle-aged men. Alcohol Alcohol. 2008; 43(3):27480.

10. Shimkhada R, Peabody JW. Tobacco control in India. Ministry of Health and Family Welfare Gol; 2003.

11. Neki NS. Lipid Profile in Chronic Smokers - A Clinical Study Key words. Clin Med (Northfield II). 2002; 3(1):51-4.

12. Rozi S, Akhtar S. Smoking among high school adolescents in Karachi, Pakistan [2]. Int J Epidemiol. 2004; 33(3):613-4.

13. Alam AY, lqbal A, Mohamud KB, Laporte RE, Ahmed A, Nishtar S. Investigating socio-economicdemographic determinants of tobacco use in Rawalpindi, Pakistan. BMC Public Health. 2008; 8(1):50-9.

14. Ali MU, Siddiqui S. Patterns of lung cancer in northwestern pakistan histopathological profile of patients with lung carcinoma: LAP Lambert Academic Publishing; 2012.

15. Siddiqui S, Ali MU, Ali MA, Shah N, Nasreen S. Lung carcinoma: its profile and changing trends. Journal of Ayub Medical College, Abbottabad: JAMC. 2010; 22(3):116-9.

16. Shaikh MA, Kamal A. Prevalence and pattern of smoking in university students - Perspective from Islamabad. J Coll Phys Surg Pak. 2004; 14(3):194-8.

17. Zafar M. Prevalence of smoking and associated risk factors among medical professionals in hospitals of Karachi, Pakistan. Int J Prev Med. 2014; 5(4):457-62.

18. Joshi N, Shah C, Mehta H, Gokhle P. Comparative study of lipid profile on healthy smoker and non smokers. Int J Med Sci Public Health 2013; 2(3):6226.

19. Chauhan P, Rishma V, Abhishek B. Comparaative study of Lipid profile and level of Antioxidant enzymes in cigarette smokers with non cigaretee smokers. Indian J Pharm Biol Res. 2013; 7(1):10-6.

20. Hassan EE, Gabra HM, Abdalla ZA, Ali AE. Effect of cigarette smoking on lipid profile in male at collage of police and Low Khartoum, Sudan. Asian J Biom Pharm Sci. 2013; 3(26):28-31.

21. Hussain SM, Ibrahim OS, Ibrahem AK. Effect of Smoking on Lipid Profile in Men in Ramadi Municipality. Al- Anbar Med J. 2009; 7(1):60-7.

22. Akbari MZA, Bhatti MS, Shakoor M. Lipid profile in smoking. J Ayub Med Coll Abbottabad. 2000; 12(3):19-21. 